
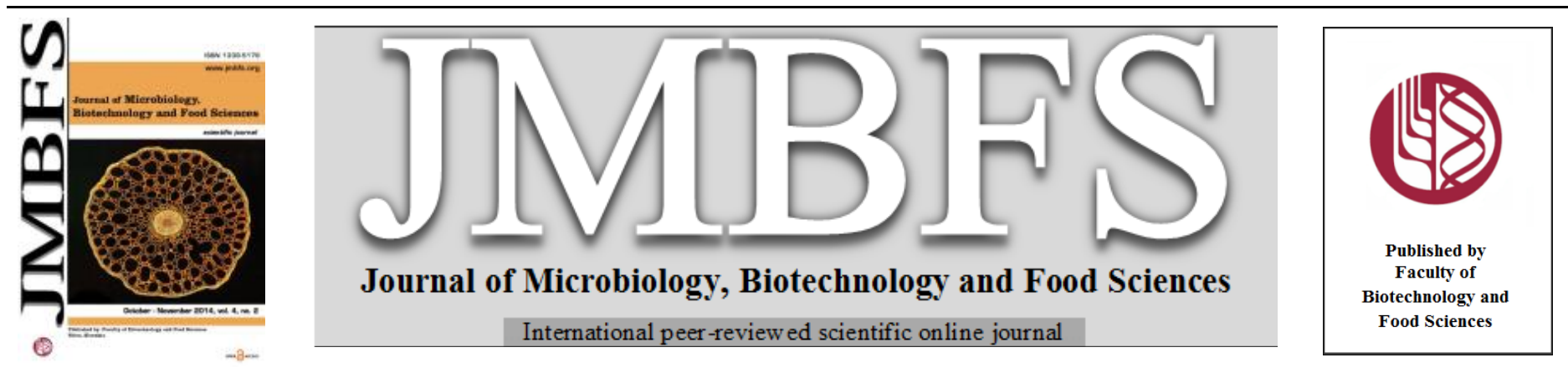

\title{
RECOVERY OF ASPERGILLUS ENDO-GLUCANASE PRODUCED ON SOLID SUBSTRATE: A DOE BASED APPROACH
}

\author{
Sibabrata Mukherjee*, Sujata Kulkarni, Milind Kulkarni
}

Address(es):

Biotech Lab, Chemical division, Thermax Ltd. 97-E, General Block, Bhosari, Pune, Maharashtra. PIN-411026. India.

*Corresponding author: siba_microbio@yahoo.co.in, sibabrata.mukherjee@thermaxindia.com

doi: 10.15414/jmbfs.2014.4.2.170-173

ARTICLE INFO

Received 10. 12. 2013

Revised 12. 9. 2014

Accepted 18. 9. 2014

Published 1. 10. 2014

Regular article open $\partial$ access

\begin{abstract}
The endo-glucanase (E.C. 3.2.1.4) was produced by Aspergillus terreus adopting solid state fermentation (SSF) using agro residues as main substrate. To recover the enzyme from the fermented mass, different extraction liquids were tried and $10 \%$ aqueous solution of glycerol was found to be superior. When the selected extractant was applied at different ratio to the fermented solid mass, maximum enzyme was recovered at 1:5 (w/v) ratio. The other process parameters (time, temperature and mixing speed) effects on the enzyme recovery were subsequently studied by response surface methodology (RSM). Box-Bhenken Design of experiment (BBDOE) was exploited for the analysis of interactive effects of the independent variables. The optimization was done following the numerical approach focusing reduction in utility cost without compromising the endo-glucanse activity. Based on the predicted solution the validation experiments were carried out and finally $32 \mathrm{IU} / \mathrm{g}$ of endo-glucanase was recovered at room temperature, at a mixing speed of $100 \mathrm{rpm}$ in $2.65 \mathrm{~h}$ which was very close to the predicted response. The optimization evidenced more than two times betterment in enzyme recovery than the un-optimized state. The model developed was found to be robust for process analysis. Repetitive extraction had revealed that maximum endo-glucanase recovery was required of two cycles of extraction at optimized conditions.
\end{abstract}

Keywords: Endo-glucanse, response surface methodology, extraction, optimization. Aspergillus

\section{INTRODUCTION}

Cellulose, the most abundant natural renewable biopolymer in the earth, is commonly degraded in to smaller fragments and finally glucose by the hydrolytic action of cellulase. The enzymatic hydrolysis generally requires synergistic action of three cellulolytic components endo-glucanase (E.C. 3.2.1.4), exoglucanase (E.C.3.2.1.91) and $\beta$-glucosidase (E.C.3.2.1.21). Cellulases as monocomponent as well as in combination are well known for their various industrial applications viz. animal feed, detergents, juice, pulp and paper, bio-fuel etc. The cellulolytic enzymes contribute to $8 \%$ of the worldwide industrial enzyme demands and the demand is expected to increase by 100\% within 2014 (Sadhu et al., 2013). The cellulase market has been estimated in the United States to be as high as US \$ 400million per year (Zhang et al., 2006).

Fungi are the main cellulase-producing microorganisms and different strains of Aspergillus has been studied for the production of cellulases sometimes particularly for endo-glucanse for production, purification, and characterization (Quyen et al., 2011).

Generally cellulases are industrially produced by submerged process but solid state fermentation (SSF) also exploited and reported based on its economics and other advantages over submerged fermentation $(\mathrm{SmF})$ described in different reports (Acuña-argüelles et al., 1995; Medina-Morales et al., 2011; Trulea $e t$ al., 2013; Sarao et al., 2013; Toor et al., 2013; Saida et al., 2013; Sharma et al., 2013). SSF is a process wherein fermentation has been done in the absence of free liquid and first stage of product (e.g. enzymes etc.) recovery from the fermented mass is mainly done by applying suitable extraction liquid to leach out the protein in the liquid phase for further processing. So development of proper process conditions for this operation is essential. Generally during SSF the end of the pipe liquid handling is lower than the $\mathrm{SmF}$ as product present in more concentrated form which eventually reduces the further down streaming costs (Gombert et al., 1999). But from the bulky solid mass, getting the product out of the system has many problems and requires proper process engineering which includes selection of suitable extractant, contact time between the fermented mass and the extractant, process temperature, mixing speed etc (Lonsane $\boldsymbol{e t}$ al., 1992). There are several reports on the optimization of recovery of different enzymes produced by SSF root (Rodríguez et al., 2012, Aikat et al., 2000, Ahmed et al 2013, Palit et al., 2001, Shata et al., 2012) but particularly on the endo-glucanase very few systematic studies have been found (Chandra $\boldsymbol{e t}$ al. 2010). Statistical technique was the important tool to solve and determine the optimal condition of enzyme extraction process. Statistical technique by BBDOE was found in many researches, wherein it had been applied to predict the optimization of biological, chemical, and physical processes (Gao et al., 2007; Mukherjee et al., 2013) because of its reasonable design and excellent outcomes. The present investigation was designed to study the interactive effects of environmental conditions on the recovery of endo-glucanase from the fermented mass using RSM and its statistical optimization.

\section{MATERIAL AND METHODS}

\section{Microorganism}

Aspergillus terreus MTCC8661 was obtained from Microbial Type Culture Collection, India. The strain was maintained on Czapek Dox agar slant at $4{ }^{\circ} \mathrm{C}$. This strain had been used for the endo-glucanase production.

\section{Chemicals and reagents}

All the chemicals used during this study were of analytical grade.

\section{SSF}

The production endo-glucanase was done adopting SSF process. Wheat bran and soy hull crushed, procured from the local market, used as the substrate. The production media composed of $16 \mathrm{~g}$ of equal amount of mixture of those two agro residues and it was supplemented with $4 \mathrm{~g}$ of cellulose powder ( Himedia Cellulose from Cotton linters RM126). The initial moisture content adjusted with the Mandel's mineral salts solution (Mandels et al., 1974) to $60 \%$ inclusive $1 \mathrm{ml}$ spore suspension. The spore suspension was prepared by harvesting the spores from 7 days old culture and suspending in sterile distilled water containing $0.01 \%$ Tween-80. The spore count was estimated using hemocytometer which was $1 * 10^{7} / \mathrm{ml}$. The media was prepared in $500 \mathrm{ml}$ Erlenmeyer flask and sterilized by autoclaving for $20 \mathrm{~min}$. and cool down at room temperature. Then the media was aseptically inoculated with the spore suspension and incubated at $30^{\circ} \mathrm{C}$ for $96 \mathrm{~h}$ in 
a humidity controlled chamber. After fermentation the extra cellular enzyme was extracted using different extraction liquid and clarified by centrifugation (10000 $\mathrm{rpm}, 20 \mathrm{~min}$, at $4^{0} \mathrm{C}$ ). The crude cell and spore free extract was used as the source of endo-glucanase.

\section{Selection of extractant}

The extractants screened to evaluate their efficacy for the endo-glucanase recovery from the fermented solid were demineralized water, tap water, distilled water, acetate buffer ( $\mathrm{pH}: 5.0)$, phosphate buffer ( $\mathrm{pH}: 5.0)$, normal saline, 10\% aqueous soln. of glycerol, $10 \%$ aqueous soln. of ethanol, $10 \%$ aqueous soln. of acetone, $0.1 \%$ aqueous soln. of Tween- $80,0.1 \%$ aqueous soln. Triton-X-100, $10 \%$ acetate buffered (pH:5.0) soln. of glycerol, $10 \%$ acetate buffered (pH:5.0) soln. of ethanol and10\% acetate buffered (pH:5.0) soln. of acetone.

Effect of the environmental conditions on the enzyme recovery from the fermented mass

To evaluate the effect of the recovery conditions and subsequent optimization, RSM was adopted. The independent parameters selected for the studies were contact time, process temperature and mixing speed. BBDOE was carried out to evaluate the influence of the selected factors and their possible interaction in the recovered enzyme activity, the response. Table 1 represented the design matrix of 17 trail experiments. Using this design, factors were prescribed into three levels, coded $-1,0$ and +1 for low, middle and high levels. Numerical optimization was done using Design Expert (Version 8.0.7., Stat-Ease Corporation, USA). For predicting the optimal point, a second order polynomial function was fitted to correlate relationship between independent variables and response (endoglucanase activity). For a three factor system the model equation was,

$Y=\beta_{0}+\beta_{1} A+\beta_{2} B+\beta_{3} C+\beta_{11} A^{2}+\beta_{22} B^{2}+\beta_{33} C^{2}+\beta_{12} A B+\beta_{23} B C+\beta_{13} A C$-..-.-. (1)

Where $Y$, predicted response; $\beta_{0}$, intercept; $\beta_{1}, \beta_{2}, \beta_{3}$, linear coefficients, $\beta_{11}, \beta_{22}$, $\beta_{33}$, squared coefficients; $\beta_{12}, \beta_{23}, \beta_{13}$, interaction coefficients and $\mathrm{A}$ contact time between fermented mass and extraction liquid (h), B is the mixing speed (rpm) and $\mathrm{C}$ is the temperature $\left({ }^{\circ} \mathrm{C}\right)$ of extraction process. The response obtained was fitted in to the polynomial equation.

Table 1 The range and level of the variables for BBDOE

\begin{tabular}{llccc}
\hline \multirow{2}{*}{ Independent variable } & \multirow{2}{*}{ Coded symbol } & \multicolumn{3}{c}{ Levels } \\
\cline { 3 - 5 } & & -1 & 0 & +1 \\
\hline Time (h) & $A$ & 1 & 2.5 & 4 \\
Mixing speed (rpm) & $B$ & 0 & 100 & 200 \\
Temperature $\left({ }^{0} \mathrm{C}\right)$ & $C$ & 25 & 30 & 35 \\
\hline
\end{tabular}

\section{Sequential extraction}

The sequential extractions employed with the best extraction liquid at optimized environmental condition for consecutive three cycles with new batch of extraction liquid every time. Fresh solvent was added to the same fermented bran and the efficiency of extraction as a function of the number of cycles needed to achieve $100 \%$ activity from the bran.

\section{Enzyme assay}

The endo-glucanase activity was assayed using 2\% CMC (Low viscosity Na salt) dissolved in $0.1 \mathrm{~N}$ acetate buffer $(\mathrm{pH}$ : 5) as substrate. The reaction mixture composed of $0.9 \mathrm{ml}$ of substrate and $0.1 \mathrm{ml}$ suitably diluted enzyme source. It was incubated for $30 \mathrm{~min}$ at $50^{\circ} \mathrm{C}$ in a shaking water bath. The reducing sugar liberated was estimated by dinitrosalicylic acid (DNSA) method (Miller. 1959).

One unit (IU) of endo-glucanase activity was defined as the amount of enzyme releasing $1 \mu \mathrm{mol}$ of reducing sugar expressed as glucose per min. The enzyme activity was expressed as IU/g of dry substrate.

\section{RESULTS AND DISCUSSION}

Selection of extractant and estimation of extractant to fermented mass ratio for the recovery of endo-glucanase produced during SSF

Different extractants (14 nos.) were applied at five volume of the fermented solid mixed at $100 \mathrm{rpm}$ for two hours at room temperature and subsequently enzyme was prepared by the same way discussed in the previous section. The $10 \%$ aqueous soln. of glycerol exhibited maximum enzyme recovery from the fermented mass (24.5 IU/g). (Fig.1). For further refinement different concentrations of glycerol were employed but marginal improvement was obtained (data not shown) consequently for the rest of the study $10 \%$ aqueous soln. of glycerol had been used as extraction liquid. The lower dielectric constant of glycerol (DK value. 13.2) probably positively supported better interaction between enzyme protein and glycerol, leading to better recovery compared to other extractants. Palit et al (2001) and Negi et al (2011) also reported maximum enzyme extraction using glycerol solution. In addition it was also found that presence of polyols (e.g. glycerol) used to inhibit the denaturation process of the enzyme in aqueous solution (Costa et al., 2002; Bourneow et al., 2012) which could also be the reason for better recovery.

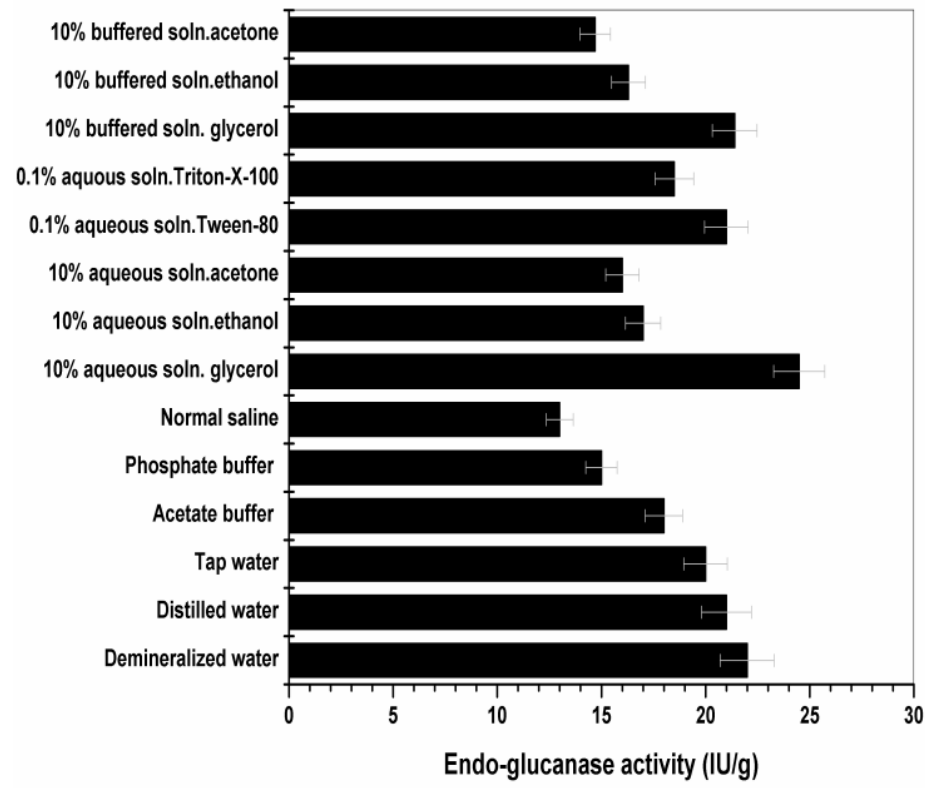

Figure 1 Effect of different extractants on the recovery of the endo-glucanase produced by SSF

In order to obtain the best solid to liquid ratio for the enzyme recovery, the fermented solid was mixed with different volume of $10 \%$ glycerol. The ratios were $(w / v), 1: 2,1: 3,1: 4,1: 5,1: 6,1: 7$. Beyond the ratio of 1:5 the enzym got diluted which in turn made the down streaming expensive and up to the ratio of $1: 3$ the enzyme was not completely leached out. The maximum enzyme recovery was achieved when 5 times of extractant was used (26 IU/g) for enzyme extraction (data not shown). So for the subsequent experiments the same ratio was used for the extraction of endo-glucanase.

Effect of the environmental conditions on the enzyme recovery from the fermented solid and statistical analysis

The BBDOE was employed to study the interactions among the significant factors and also determined their optimal levels. The effect of different levels of the three factors on the endo-glucanase activity was shown in Table 2 . Experimental results obtained were fitted to a second-order polynomial equation (Equ.2) by applying multiple regression analysis.

Enzyme activity $(I U / g)=29.90+1.30 * A+3.88 * B+0.58 * C-0.50 * A * B$ $+0.60 * A * C-1.75 * B * C-4.63 * A^{2}-4.27 * B^{2}-6.38 * C^{2}$.-The predicted and actual response had been shown in the Table 2 . The maximum and minimum enzyme recovery was achieved in this study were $31.5 \mathrm{IU} / \mathrm{g}$ and 15 IU/g respectively. The residual analysis was also done applying the predicted vs actual plotting and the points found to be randomly scattered along the $45^{\circ}$ line depicted the accuracy of the model. (Fig 2 a). ANOVA results for the RSM were given in Table 3. The model was found to be significant and the lack of fit was not significant at $95 \%$ confidence level. 
Table 2 BBDOE matrix with predicted and experimental values of response.

\begin{tabular}{lccccc}
$\begin{array}{l}\text { Standard } \\
\text { Order }\end{array}$ & $\begin{array}{c}\text { Time } \\
(\mathrm{h})\end{array}$ & $\begin{array}{c}\text { Mixing } \\
(\mathrm{rpm})\end{array}$ & $\begin{array}{c}\text { Temp } \\
\left({ }^{0} \mathrm{C}\right)\end{array}$ & \multicolumn{2}{c}{\begin{tabular}{c} 
Endo-glucanase activity \\
\cline { 5 - 6 }
\end{tabular}} \\
& & & & $\begin{array}{c}\text { Actual } \\
\text { Value }\end{array}$ & $\begin{array}{c}\text { Predicted } \\
\text { Value }\end{array}$ \\
\hline 1 & -1 & -1 & 0 & 15 & 15.325 \\
2 & 1 & -1 & 0 & 18 & 18.925 \\
3 & -1 & 1 & 0 & 25 & 24.075 \\
4 & 1 & 1 & 0 & 26 & 25.675 \\
5 & -1 & 0 & -1 & 17 & 17.625 \\
6 & 1 & 0 & -1 & 19 & 19.025 \\
7 & -1 & 0 & 1 & 17.6 & 17.575 \\
8 & 1 & 0 & 1 & 22 & 21.375 \\
9 & 0 & -1 & -1 & 14 & 13.05 \\
10 & 0 & 1 & -1 & 24 & 24.3 \\
11 & 0 & -1 & 1 & 18 & 17.7 \\
12 & 0 & 1 & 1 & 21 & 21.95 \\
13 & 0 & 0 & 0 & 29 & 29.9 \\
14 & 0 & 0 & 0 & 31 & 29.9 \\
15 & 0 & 0 & 0 & 28 & 29.9 \\
16 & 0 & 0 & 0 & 30 & 29.9 \\
17 & 0 & 0 & 0 & 31.5 & 29.9 \\
\hline
\end{tabular}

Table 3 ANOVA and the regression analysis of the endo-glucanase recovery.

\begin{tabular}{lccccc}
\hline Source & $\begin{array}{c}\text { Sum of } \\
\text { Squares }\end{array}$ & DF & $\begin{array}{c}\text { Mean } \\
\text { Square }\end{array}$ & $\begin{array}{c}\text { F } \\
\text { Value }\end{array}$ & $\begin{array}{c}\text { p-value } \\
\text { Prob > F }\end{array}$ \\
\hline Model & 527.1076 & 9 & 58.56752 & 31.80548 & $<0.0001$ \\
A-Time & 13.52 & 1 & 13.52 & 7.342126 & 0.0302 \\
B-Mixing & 120.125 & 1 & 120.125 & 65.23468 & $<0.0001$ \\
C-Temp & 2.645 & 1 & 2.645 & 1.436385 & 0.2697 \\
AB & 1 & 1 & 1 & 0.543057 & 0.4851 \\
AC & 1.44 & 1 & 1.44 & 0.782002 & 0.4059 \\
$B^{\wedge}$ & 12.25 & 1 & 12.25 & 6.652444 & 0.0365 \\
$A^{\wedge} 2$ & 90.06579 & 1 & 90.06579 & 48.91082 & 0.0002 \\
$B^{\wedge} 2$ & 76.95 & 1 & 76.95 & 41.78821 & 0.0003 \\
$C^{\wedge 2}$ & 171.1184 & 1 & 171.1184 & 92.92699 & $<0.0001$ \\
Residual & 12.89 & 7 & 1.841429 & & \\
Lack of Fit & 4.69 & 3 & 1.563333 & 0.762602 & 0.5711 \\
Pure Error & 8.2 & 4 & 2.05 & & \\
Cor Total & 539.9976 & 16 & & & \\
\hline Legend: DF: degrees of freedom: F: variance ratio: P: probability. &
\end{tabular}

Legend: DF: degrees of freedom; F: variance ratio; P: probability.

Among the three independent model terms viz. time and mixing speed were found to be significant in the experimental range. The goodness of fit of the model was checked by determination coefficient $\left(R^{2}\right)$. In this case, the value of the determination coefficient $\left(\mathrm{R}^{2}=97.61\right)$ indicated that only $2.39 \%$ of the total variation could not be explained by the model. The value of the adjusted determination coefficient (Adj $\mathrm{R}^{2}=0.9454$ ) was also expressed the mode significance. The "Pred R-Squared" of 0.8373 was in reasonable agreement with the "Adj R-Squared" of 0.9454. Additionally the adeq precisior ratio of 16.19 indicated an adequate signal and the model could be used for the navigation of design space. The 3D response surfaces were drawn to present the interactive effects of three independent factors and to present the combined effects of those factors on the endo-glucanase activity. From the Fig $2 b$, it was clear that the increase in contact time between the fermented mass and the $10 \%$ aqueous glycerol solution was effective for the enzyme recovery. Time of $2.5 \mathrm{~h}$ was actually found to be sufficient for the leaching out of maximum enzyme in liquid phase at $100 \mathrm{rpm}$ shaking condition. Beyond this range further increase in mixing speed and contact time showed marginal effect on the recovery. At higher temperature $\left(35^{\circ} \mathrm{C}\right)$ the recovery found to be low may be due to the thermal distortion of the enzyme structure but the range of $25-30^{\circ} \mathrm{C}$ which has also covered the room temperature given acceptable recovery even at lower contact time (1.5-2h).(Fig $2 \mathrm{c})$. The contour covering the temperature range of $28-31^{\circ} \mathrm{C}$ and the mixing speed of 100-150 rpm represented maximum recovery (Fig 2d). During the analysis of interactive effect of two factors on the response the remaining was kept constant at its middle point. Further optimization was done following numerical optimization using the Design expert software. The temperature of operation was targeted as room temperature $\left(25^{\circ} \mathrm{C}\right)$ and the mixing speed targeted to $100 \mathrm{rpm}$ instead of the range of $0-200 \mathrm{rpm}$ to reduce the utility cost as well as adverse shearing effect on the protein structure. Time of contact was kept in its range and the response was set to be maximized. The validation experiment was done based on the solution received using the model. Finally 32 $\mathrm{IU} / \mathrm{g}$ of endo-glucanase was achieved when the values of the independent factors were time $(2.65 \mathrm{~h})$, mixing $(100 \mathrm{rpm})$ and temperature $\left(26^{\circ} \mathrm{C}\right)$. The desirability value for the prediction was obtained was 0.847 which was close to 1 . Using the model the enzyme recovery had been increased of more than two times compared to unoptimized enzyme recovery.
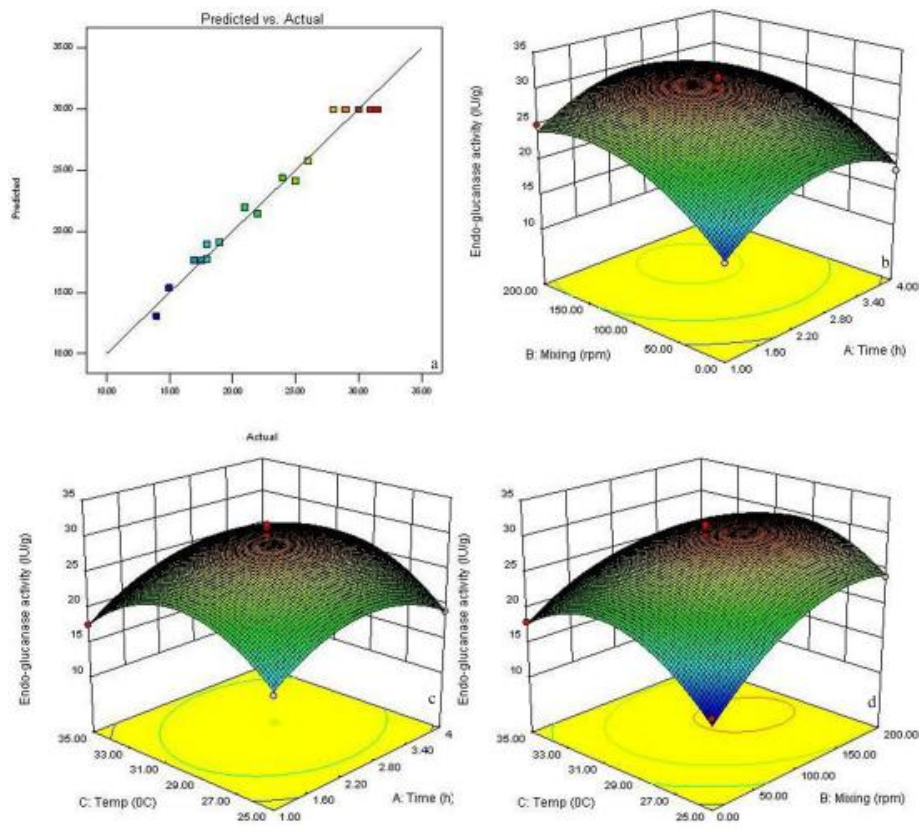

Figure 2 Predicted vs. actual values plot for endo-glucanase activity (a) Response surface and contour plot (base) of enzyme activity (IU/g) showing the interactions among contact time and mixing speed (b), contact time and process temperature (c) and process temperature and mixing speed (d).

\section{Sequential extraction of endo-glucanase produced during SSF.}

The efficiency of extraction of the endo-glucanase from the fermented mass with $10 \%$ aqueous glycerol solution at the optimal solid to liquid ratio $(1: 5 \mathrm{~g} / \mathrm{mL})$ was carried out in four consecutive cycles at the optimized extraction conditions. Fresh extraction liquid was added in each cycle to the fermented mass. It was found that two cycles of extraction were sufficient for the maximum endoglucanase from the fermented mass (data not shown). Rashid et al., 2013 also report maximum enzyme recovery with two washes. After the second extraction the enzyme recovered from the mass was negligible as it was considerably diluted.

\section{CONCLUSION}

From the industrial view point the maximum product recovery is always essential as it immediately reflects on the process cost. In the present study a systematic approach was taken for a model development for the maximum recovery of endoglucanase, an industrially important, multipurpose enzyme. The enzyme was produced by SSF using low cost agro residues viz. wheat bran and soy hull crushed. The 10\% glycerol solution was found to be the best extractant for the leaching out of the enzyme from the fermented solid mass. The BBDOE approach was proved to be very effective and robust to optimize the recovery process as well as to analyze the interactive effects of the process parameters and it was validated with the actual trials. Repeated endo-glucanase extraction was required up to two cycles to recover maximum endo-glucanase in the solution phase.

Acknowledgments: The R\&D work was supported by Thermax Ltd. India.

\section{REFERENCES}

ACUÑA-ARGÜELLES, M.E., GUTIÉRREZ-ROJAS, M., VINIEGRAGONZÁLEZ, G., FAVELA-TORRES, E. 1995. Production and properties of three pectinolytic activities produced by Aspergillus niger in submerged and solid state fermentation. Applied Microbiology and Biotechnology, 43, 808-814. http://dx.doi.org/10.1007/bf02431912

AHMED, S. A. AND MOSTAFA, F. A. 2013. Utilization of orange bagasse and molokhia stalk for production of pectinase enzyme. Brazilian Journal of Chemical Engineering, 30 (03), 449 - 456. http://dx.doi.org/10.1590/s010466322013000300003

AIKAT, K., BHATTACHARYYA, B.C. 2000. Protease extraction in solid state fermentation of wheat bran by a local strain of Rhizopus oryzae and growth studies by the soft gel technique Process Biochemistry, 35, 907-914. http://dx.doi.org/10.1016/s0032-9592(99)00148-x

BOURNEOW, C., BENJAKUL, S., H-KITTIKUN A. 2012. Impact of some additives on the stability of microbial transglutaminase from Providencia $s p$. C1112. As. J. Food Ag-Ind., 5(03), 226-233

CHANDRA, M.S., BUDDOLLA, V., REDDY, B. R. 2010. Optimization of extraction of $\beta$-endoglucanase from the fermented bran of Aspergillus niger 
Indian J Microbiol, 50 (Suppl 1), 122-126. http://dx.doi.org/10.1007/s12088010-0020-2

COSTAA, S. A., TZANOVA, T., CARNEIROA, A. F., PAARB, A., GU“BITZB, G. M., CAVACO-PAULOA A. 2002. Studies of stabilization of native catalase using additives. Enzyme and Microbial Technology, 30, 387-391. http://dx.doi.org/10.1016/s0141-0229(01)00505-1

GAO, H. AND GU, W. Y. 2007. Optimization of polysaccharide and ergosterol production from Agaricus brasiliensis by fermentation process. Biochemical Engineering Journal, 33, 202-210. http://dx.doi.org/10.1016/j.bej.2006.10.022 GOMBERT, AK., PINTO, AL., CASTILHO, LR., FREIRE, DMG. 1999. Lipase production by Penicillium restrictum in solid-state fermentation using babassu oil cake as substrate. Process Biochem., 35, 85-90. http://dx.doi.org/10.1016/s0032-9592(99)00036-9

LONSANE, BK. AND KRISHNAIAH, MM. 1992. Product leaching and downstream processing. In Solid substrate Cultivation, Doelle HW, Mitchell DA, and Rolz CE (eds.) , 147-153. Elsevier Science Publishers, London, UK.

SHATA, H. M. A. H., FARID, M.A. F. 2012. Optimization of Extraction Parameters for Keratinase Recovery from Fermented Feather under Solid State Fermentation by Streptomyces sp. NRC 13S. J Appl Biol Chem, 55(3), 149-156. http://dx.doi.org/10.3839/jabc.2012.023

SAIDA, L., OBEROI, H. S., NARASU, M.L. 2013. Studies on Cellulase Production by Solid state Fermentation using Sweet Sorghum bagasse. Helix , 1, 261-266.

MANDELS, M., HONTZ, I., NYSTROM, J. 1974. Enzymatic hydrolysis of waste cellulose. Biotecnology and Bioengineering, 16, 1471-1493. http://dx.doi.org/10.1002/bit.260161105

MEDINA-MORALES, M. A., MARTÍNEZ-HERNÁNDEZ J. L., GARZA, H., AGUILAR, C. N. 2011. Cellulolytic Enzymes Production by Solid State Culture Using Pecan Nut Shell as Substrate and Support. Am. J. Agri. \& Biol. Sci., 6 (2), 196-200. http://dx.doi.org/10.3844/ajabssp.2011.196.200

MILLER GL. 1959. Use of dinitrosalicyclic acid reagent for determination of reducing sugar. Anal Chem, 31, 426-8. http://dx.doi.org/10.1021/ac60147a030

MONICA ATTRI, ARORA MANINDER, LOVELEEN KAUR SARAO. 2013.

Production and partial purification of microbial enzymes cellulase and laccase using a laboratory designed solid state fermenter. International Journal of Applied Research and Studies, 2 (8).

MUKHERJEE, S., KULKARNI, M., KULKARNI, S., NAIK, S. 2013. Covalent immobilization of amyloglucosidase on Tulsion ${ }^{\circledR}$ weak base anionic resin: optimization by Box-Behnken DOE followed by thermal characterization. The Journal of Bioprocess Technology. Photon, 98, 293-302.

NEGI, S., GUPTA1, S., BANERJEE, R. 2011. Single-Stage Fermentation of Glucoamylase and Protease by A. awamori, Food Technol. Biotechnol., 49 (3), 310-315.

PALIT, S., BANERJEE, R. 2001. Optimization of Extraction Parameters for Recovery of $\alpha$ - amylase from the Fermented Bran of Bacillus circulans GRS313. Brazilian archives of biology and technology, 44, 107 - 111. http://dx.doi.org/10.1590/s1516-89132001000100015

PHAM, T. H., QUYEN, D. T., NGHIEM, N. M.2012. Purification and properties of an endoglucanase from Aspergillus niger VTCC-F021. Turk J Biol, 36,694701

RODRÍGUEZ, F. D., RODRÍGUEZ, L. J., DE, C. J.C., KARP, SG., PARADA, JL. 2012 Process Development to Recover Pectinases Produced by Solid-State Fermentation. J Bioprocess Biotechniq, 2:121 http://dx.doi.org/10.4172/21559821.1000121.

SADHU, S., GHOSH, P. K., DE, T. K., MAITI, T. K. 2013. Production, purification and characterization of a novel thermotolerant endoglucanase (CMCase) from Bacillus strain isolated from cow dung. SpringerPlus, 2, 2-10 http://dx.doi.org/10.1186/2193-1801-2-10

SHARMA, H. K., BURNWAL, P. K., DUBEY L., RAO, R.J. 2013. Optimization and Production of Cellulase from Agricultural Waste. Research Journal of Agriculture and Forestry Sciences, 1(7), 18-20.

TOOR, Y., ILYAS, U. 2013. Optimization of cellulase production by Aspergillus ornatus by the solid state fermentation of Cicer arietinum. American Journal of Research Communication, www.usa-journals.com, ISSN: 2325-4076.

TRULEA, A., VINTILA, T., POP, G., MONICA, D. 2013. Effects of Bioprocess Parameters on Production of Cellulase using Miscanthus as Substrate. Animal Science and Biotechnologies, 46 (1), 149-154.

ZHANG, YHP., HIMMEL, ME., MIELENZ, JR. 2006. Outlook of cellulase improvement: screening and selection strategies. Biotechnology advances, 24,452-481. http://dx.doi.org/10.1016/j.biotechadv.2006.03.003 